\title{
Contribution of Leg Flexibility, Limb Length, Leg Power for the Split Leap Skills of Rhythmic Gymnastics Athletes
}

\author{
Ranu Baskora Aji-Putra", Tommy Soenyoto, Agus Darmawan, Roas Irsyada \\ Sport Science Faculty, Universitas Negeri Semarang, Semarang, Indonesia
}

Received March 21, 2021; Revised April 28, 2021; Accepted May 28, 2021

\section{Cite This Paper in the following Citation Styles}

(a): [1] Aji-Putra Ranu Baskora, Tommy Soenyoto, Agus Darmawan, Roas Irsyada , "Contribution of Leg Flexibility, Limb Length, Leg Power for the Split Leap Skills of Rhythmic Gymnastics Athletes," International Journal of Human Movement and Sports Sciences, Vol. 9, No. 4, pp. 648 - 653, 2021. DOI: 10.13189/saj.2021.090407.

(b): Ranu Baskora Aji-Putra, Tommy Soenyoto, Agus Darmawan, Roas Irsyada (2021). Contribution of Leg Flexibility, Limb Length, Leg Power for the Split Leap Skills of Rhythmic Gymnastics Athletes. International Journal of Human Movement and Sports Sciences, 9(4), 648 - 653. DOI: 10.13189/saj.2021.090407.

Copyright $\bigcirc 2021$ by authors, all rights reserved. Authors agree that this article remains permanently open access under the terms of the Creative Commons Attribution License 4.0 International License

\begin{abstract}
This study examined the association between leg flexibility, leg length, jump height, and split leap movement scores at various levels of rhythmic gymnasts. Fifty-two young rhythmic gymnasts (age: 10.63 \pm 2.9 years) were divided into two groups (qualifying, $\mathrm{n}=$ 32 and non-qualifying, $\mathrm{n}=20$ ) based on age and regional championship level. The gymnast underwent a series of fitness tests in the form of leg flexibility and leg explosive power as well as a split jump performance which was judged by 2 national and international certified judges. There was a significant difference and correlation between qualification and non-qualification in the split leap score $(\mathrm{p}$ $=0.00)$, body weight $(\mathrm{p}=0.00 ; \mathrm{r}=0.351)$, limb length $(\mathrm{p}=$ $0.00 ; r=0.420)$, High Jump $(p=0.01 ; r=0.279)$, raised straight legs $(p=0.021 ; r=-0.279)$. There was no difference found in point feet but positively related at split leap score $(\mathrm{p}=0.386 ; \mathrm{r}=0.373)$. The overall multiple regression analysis of all novice athletes revealed that Limb length, point feet, and high jump accounted for a medium part (32\%) of the split leap score. In conclusion, the level of the gymnast (non-qualification), weight, Limb length, and arm length had a greater effect on the implementation of the split leap, whereas at the junior level (qualification) the leg explosiveness and flexibility of the leg effectively contributed to the split leap movement. Overall, the athlete's flexibility, body composition, and the explosive power of the limb variables effectively contribute to the split leap movement in youth rhythmic
\end{abstract}

gymnastics.

Keywords Split Leap, Leg Power, Rhythmic Gymnastic

\section{Introduction}

The split leap is the movement of stretching the leg asymmetrically opposite as much as possible and can be accompanied by manipulating tools. The anthropometric view of the Rhythmic gymnast with the characteristics of a tall, slender body with long legs would be more advantageous in the beauty of her movements and the judges' judgment [1-5].

This makes the split leap a complex movement because at the start of the movement, refusing the foot to float, can be combined with manipulating the throwing tool and catching it again on landing or in midair. In this movement, the gymnast must also adjust to the musical accompaniment. For elite athletes, split leap rhythmic gymnastics is not a significant problem because they have trained all the supporting elements of this movement. However, for beginners and juniors, split leap rhythmic gymnastics requires the right combination of elements of speed, leg flexibility, and leg power in displaying their motion. Muscle flexibility and joint flexibility support a 
functional movement of the body. Anatomical limitations of the body cause disruption of freedom of movement [6,7]. The importance of flexibility in all physical activities requires a person to prepare one component of the physical condition of flexibility in every warm-up. In rhythmic gymnastics, gymnasts are required to have high flexibility to support their best performance [8,9]. The study shows that there is a relationship between high flexibility and a reduction in the value of the jury when performing movement skills in rhythmic gymnastics athletes [9]. Another influential variable according to the study states that power is one of the main elements other than flexibility which determines the ability of Rhythmic Gymnastics [10-12]. The Split Leap movement requires complex physical components of speed, power and flexibility [13]. Rhythmic gymnastics skills are a series of combinations of basic ballet movements, body flexibility, expressions combined with rhythm by manipulating rope, hoops, clubs, balls, and ribbons. The main elements of rhythmic gymnastics are running, jumping, throwing, catching, balancing, turning, and landing $[14,15]$. In rhythmic gymnastics, the gymnast displays a combination of the series according to the Code of Point Book in selecting his movements according to the rules, namely difficulty, mastery (AD), throws (R) and dance steps. The series was carried out with musical accompaniment which lasted one and a half (01.30) minutes [16]. In rhythmic gymnastics itself, various kinds of numbers are contested along with music, dance combinations, and movement difficulty factors also have movement requirements [17]. Failure to perform a perfect split leap will result in a reduction in the score by the judges as well as an impact on the appearance of the next series of moves. The results of interviews with the beginner (non-qualifiers) and junior (qualifiers) rhythmic gymnastics coach Wimilia at Unnes central java Indonesia stated that for the beginners' athletes it is difficult to display this movement because in addition to needing proper coordinative training, each element of support for the split leap motion such as jumping and leg stretching/splits, this is on average. On the other hand, they are not yet mature in their coordinative movements and combine with instruments and musical accompaniment. This problem was interesting to study more deeply about how much limb flexibility, power, and leg length contribute to the split leap movement. So that the coach can improve the basic physical abilities of rhythmic gymnastics athletes with the right concerns regarding leg flexibility, or leg power. The purpose of this study was to analyze the contribution of leg flexibility, leg strength, and leg length to the split leap movement.

\section{Materials and Methods}

The method used in this research is a survey method with an ex post facto research design. Which is used to determine leg length, pelvic flexibility, power, and ability split leap for Beginner and Junior Rhythmic gymnastics in
Central Java. A total of 52 rhythmic gymnasts participated in this study. The data collection procedures were carried out by researchers, including managing research permits, audiences with policymakers, socialization of research plans with the official organization of gym (Persani) Central Java, identification of subjects, population and research samples, preparation of instruments, recruitment, and training of data collection teams, data collection of athletes, and data analysis. The data collection instruments used in this study consisted of: Anthropometric measurements of height and leg length using image posture analysis, UNG (Real Image Size) software which has been tested for the reliability of 0.95 and validity of 0.91 with standard length measuring instrument no. Reg C4 / VI / 250419 and body weight were measured using a body scale. Measurement of flexibility (ROM) associated with the split leap motion using Kinovea software. Kinovea software is a valid and reliable tool that is able to measure accurately at distances up to $5 \mathrm{~m}$ from the object and at an angle range of $90^{\circ}-45^{\circ}$. Measurement of hip joint flexibility is measured by image analysis by recording images of leg flexion by lying perpendicular to the back of the floor and lifting the leg forward as widely as possible and leg extension by lying on the stomach lifting the leg towards the back. Also, limb abduction is measured by lying on the side and lifting the leg sideways. The joints of the feet are measured by recording images and analyzing by sitting straight with the knees touching the floor and doing maximum flexion of the tapered leg (point) and extension of the knee leg in the same way. Measuring leg power using a standing long jump is a measurement instrument that can see the power criteria for a certain age [18]. Judging of the Split Leap Movement (with criteria by nationally licensed Jury) with the criteria according to motion as discrete motion. [19]. The split leap element fulfills the criteria as shown in table 1 below.

Table 1. Grid of Split Leap assessment instruments

\begin{tabular}{|c|c|c|}
\hline Section & Motion Decription & $\begin{array}{c}\text { Maximum } \\
\text { Value }\end{array}$ \\
\hline prefix & $\begin{array}{l}\text { 1. Beginning with the gymnast's stance, } \\
\text { standing upright. } \\
\text { 2. The initial jump can use a step or a jump by } \\
\text { moving the arm from the bottom up } \\
\text { 3. The knees are bent to provide momentum and } \\
\text { a boost of power to jump upwards. } \\
\text { 4. The body is straight, the chin and the view are } \\
\text { straight slightly raised }\end{array}$ & 4 \\
\hline $\begin{array}{c}\text { impleme } \\
\text { ntation }\end{array}$ & $\begin{array}{l}\text { 1. Body remains perpendicular to the view } \\
\text { towards the front } \\
\text { 2. Quickly raise both legs asymmetrically until } \\
\text { they are stretched out } 180^{\circ} \text { in the air } \\
\text { 3. Quickly close the legs back with the arms } \\
\text { down }\end{array}$ & 6 \\
\hline landing & $\begin{array}{l}\text { 1. Hands move towards the side or front } \\
\text { 2. Landing using the leg with the knee bent } \\
\text { against the force of gravity to hold the body } \\
\text { 3. Standing in a perfect posture without } \\
\text { additional steps, arms upright body position } \\
\text { forward view }\end{array}$ & 3 \\
\hline
\end{tabular}




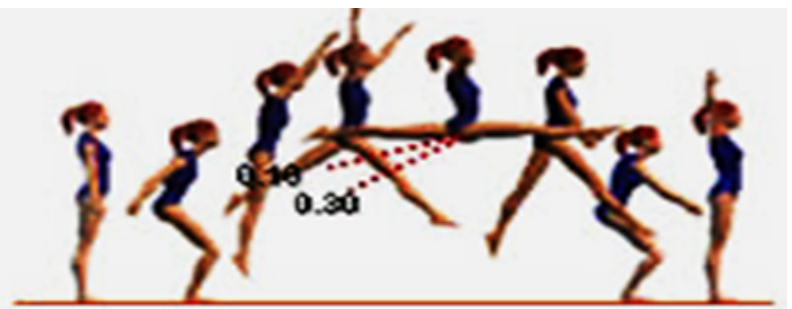

Figure 1. Discrete Point Split Leap Deduction

Data analysis includes 1). rechecking the collected data; 2). Sort and analyze images to get accurate data. The data obtained were analyzed to describe the anthropometric characteristics of rhythmic gymnasts, the quality of flexibility, and the leg power of novice and junior rhythmic gymnasts. The hypothesis of this study states that there is an effect of leg length, leg power, and hip flexibility on the split leap ability of novice athletes and junior athletes in Semarang. And to answer the hypothesis, inferential statistical analysis is used, namely the multivariate analysis of variance (ANOVA). After that, Regression Analysis will be used to determine the contribution of the independent variable to the dependent variable, namely the ability to split leap of beginner and junior rhythmic athletes. The analysis will be continued by calculating the effective contribution (SE) to determine which variable is more dominant in the Split Leap movement. A Relative Contribution (SR) will also be sought to understand the contribution to RSquare.

\section{Result}

The description of the research data is as shown 2 below in table:

Table 2. Descriptive characteristics of the participants. Data are means \pm SD

\begin{tabular}{ccccc}
\hline group & $\begin{array}{c}\text { Age } \\
(\mathrm{y})\end{array}$ & $\begin{array}{c}\text { Height } \\
(\mathrm{cm})\end{array}$ & $\begin{array}{c}\text { Body } \\
\operatorname{mass}(\mathrm{Kg})\end{array}$ & IMT \\
\hline Non-qualifiers & $8.75 \pm$ & $130.43 \pm$ & $26.68 \pm$ & $15.50 \pm 1.79$ \\
$\mathrm{n}=32$ & 1.2 & 10.77 & 5.88 & \\
\hline Qualifiers & 13.65 & $150.15 \pm$ & $41.21 \pm$ & $18.1 \pm 2.21$ \\
$\mathrm{n}=20$ & $\underline{ \pm 2.05}$ & 7.38 & 7.18 & \\
\hline
\end{tabular}

A good split leap score will be significantly higher in junior athletes (Qualifier) compared to novice athletes (non-Qualifiers. Junior athletes excel at far jumps and leg ranges) can be seen in Table 3 below.

There was no significant difference between the two groups of beginners and juniors regarding the flexibility of the legs towards the front of both the right and left legs and the points of the feet. In general, junior athletes had superior jump tests, flexibility, and physical size (Table 3 ). The value of the split jump by two international certified judges correlates with several physical variable items tested in the beginner group, namely body weight, leg length, and leg variable point. Meanwhile, there is a correlation between the juniors in long-jump and point feet (Table 3). Meanwhile, if the two groups are combined, the correlation with the split leap value is the variable weight, leg length, jump height, and point feet, and negatively correlated with the flexibility of the right leg to the back. Multiple regression analysis revealed that body weight and arm length and leg length accounted for a portion (25\%) of the variance in the split leap score for non-qualifiers, while for qualification only $26.7 \%$ of the split leap score difference was calculated by jump length and point feet (Table 4).

Table 3. Comparison of Split leap assement score and physical fitness assessment test results (mean \pm SD) between Qualifiers and non-Qualifiers. The correlations between the motion elemen score and physical fitness variables are presented separately for Qualifiers and non-Qualifiers.

\begin{tabular}{|c|c|c|c|c|c|c|}
\hline $\begin{array}{c}\text { Physical fitness } \\
\text { variables }\end{array}$ & $\begin{array}{c}\text { Non-qualifiers } \\
n=32\end{array}$ & $\begin{array}{c}\text { Qualifiers } \\
n=20\end{array}$ & $P$ & $\begin{array}{c}\text { Pearson's r } \\
\text { Non qualifiers }\end{array}$ & $\begin{array}{l}\text { Pearson's } \\
\text { qualifiers }\end{array}$ & $\begin{array}{c}\text { Pearson's } \\
\text { All Partisipant }\end{array}$ \\
\hline $\begin{array}{l}\text { Split leap assement } \\
\text { score }\end{array}$ & $6.25 \pm 2.73$ & $8.05 \pm 3.14$ & 0.00 & & & \\
\hline Body Mass (Kg) & $26.68 \pm 5.88$ & $41.21 \pm 7.1$ & 0.00 & $0.410^{*}$ & 0.02 & $0.351 *$ \\
\hline limb length $(\mathrm{cm})$ & $71.65 \pm 7.3$ & $85.05 \pm 6.6$ & 0.00 & $0.382 *$ & 0.165 & $0.420 * *$ \\
\hline Torso length $(\mathrm{Cm})$ & $32.53 \pm 3.80$ & $36.80 \pm 3.44$ & 0.00 & 0.194 & -0.089 & 0.148 \\
\hline Arm length $(\mathrm{Cm})$ & $41.75 \pm 4.59$ & $47.80+3.91$ & 0.00 & 0.249 & -0.228 & 0.242 \\
\hline Longjump (Cm ) & $94.3+24.38$ & $109.9 \pm 26.3$ & 0.03 & 0.042 & $0.448 * *$ & 0.116 \\
\hline Height jump (Cm) & $18.82 \pm 6.57$ & $24.83 \pm 8.03$ & 0.01 & 0.203 & 0.378 & $0.279 *$ \\
\hline $\begin{array}{l}\text { Right legs straight } \\
\text { head }\left({ }^{0}\right)\end{array}$ & $86.59 \pm 9.42$ & $6.35 \pm 12.88$ & 0.961 & 0.105 & 0.290 & 0.048 \\
\hline $\begin{array}{c}\text { Right legs straight } \\
\operatorname{back}\left({ }^{0}\right)\end{array}$ & $49.43 \pm 15.05$ & $39.90 \pm 12.37$ & 0.021 & -0.161 & -0.293 & $-0.275^{*}$ \\
\hline $\begin{array}{c}\text { Left legs straight } \\
\text { ahead }\left({ }^{0}\right)\end{array}$ & $84.3 \pm 15.4$ & $84.35+11.2$ & 0.993 & 0.025 & 0.224 & 0.08 \\
\hline $\begin{array}{l}\text { Left legs straight ahead } \\
\qquad\left(^{0}\right)\end{array}$ & $53.75+26.72$ & $42.95+11.90$ & 0.05 & 0.086 & -0.240 & -0.148 \\
\hline Flat feet $\left({ }^{0}\right)$ & $78.53+16.82$ & $90.9+6.49$ & 0.009 & 0.072 & 0.241 & 0.173 \\
\hline Point Feet $\left({ }^{0}\right)$ & $157.4 \pm 6.49$ & $159.1+6.95$ & 0.386 & -0.041 & $0.497 * *$ & $0.373 * *$ \\
\hline
\end{tabular}


Table 4. Results of the multiple regression analyses using assessment Split leaps variablesas predictors of performance split leap for Qualifiers and non-Qualifiers

\begin{tabular}{|c|c|c|c|c|c|}
\hline Non qualifiers & $\begin{array}{c}\text { Standardized } \\
\text { beta coefficient }\end{array}$ & Adjusted R2 & $\begin{array}{c}\mathrm{t} \\
\text { (Sig.) } \\
\end{array}$ & $\begin{array}{c}\mathrm{F} \\
\text { (Sig.) }\end{array}$ & $\mathrm{R}$ \\
\hline Motion element assessment & & 0.259 & 0.338 & \multirow{4}{*}{$0.036^{*}$} & \multirow{4}{*}{0.502} \\
\hline berat & 0.501 & & 0.079 & & \\
\hline Arm length & -0.388 & & 0.227 & & \\
\hline Limb length & 0.327 & & 0.179 & & \\
\hline Qualifiers & $\begin{array}{c}\text { Standardized } \\
\text { beta coefficient }\end{array}$ & Adjusted R2 & $\begin{array}{c}\mathrm{t} \\
\text { (Sig.) }\end{array}$ & $\begin{array}{c}\text { F } \\
\text { (Sig.) }\end{array}$ & $\mathrm{R}$ \\
\hline Motion element assessment & & 0.267 & 0.10 & \multirow{3}{*}{$0.028 *$} & \multirow{3}{*}{0.586} \\
\hline Long jump & 0.327 & & 0.13 & & \\
\hline Point feet & 0.397 & & 0.07 & & \\
\hline
\end{tabular}

Table 5. Results of the multiple regression analyses using assessment Split leaps variablesas predictors of performance split leap for all sample

\begin{tabular}{|c|c|c|c|c|c|}
\hline All Sampel & $\begin{array}{c}\text { Standardized } \\
\text { beta coefficient }\end{array}$ & RSquare & $\begin{array}{c}\mathrm{t} \\
\text { (Sig.) }\end{array}$ & $\begin{array}{c}\mathrm{F} \\
\text { (Sig.) }\end{array}$ & $\mathrm{R}$ \\
\hline Motion element assessment & & 0.320 & 0.05 & \multirow{4}{*}{$0.00^{*}$} & \multirow{4}{*}{0.566} \\
\hline Point feet & 0.342 & & 0.06 & & \\
\hline high jump & 0.176 & & 0.162 & & \\
\hline Limb length & 0.342 & & 0.008 & & \\
\hline
\end{tabular}

$*: \mathrm{p}<0.05$

The combined analysis of the split leap participants' performances using linear regression states that as much as $32 \%$ of the Split Leap value depends on the point feet, jump height, and leg length. The significance value of $\mathrm{F}$ sig $0.00<0.05$ proves that the independent variable point feet, high jump, and limb length can predict the performance value of the split leap movement of all samples of rhythmic athletes. It appears that the relationship between the variables and the athlete's split movement value has a strong positive correlation (Table 5). The total relative contribution shows $99.90 \%$ of the percentage size of the contribution of a predictor variable to the number of squares of the regression. While the total effective contribution explains the overall predictions that can be explained by $32 \%$ rounding off the effectiveness of the regression line. So the remaining $68 \%$ is influenced by other factors such as length of exercise, psychological factors (Tabel 6).

Table 6. Effective contribution and relative contribution independent variable to the motion element Split leap assessment

\begin{tabular}{ccc}
\hline All athletes & $\begin{array}{c}\text { Effective } \\
\text { Contribution }\end{array}$ & relative contribution \\
\hline Point feet & $12.75 \%$ & $39.8 \%$ \\
\hline High jump & $4.9 \%$ & $15.3 \%$ \\
\hline Limb length & $14.34 \%$ & $44.8 \%$ \\
\hline Total & $31.99 \%$ & $99.90 \%$ \\
\hline
\end{tabular}

\section{Discussion}

The main findings in this study include differences in the characteristics of novice rhythmic gymnastics athletes in their split jump performance on several items, namely, point feet and forward leg flexibility. Interestingly, the correlation between the value of the split jump was only on the physical characteristics of the bodyweight and leg length in the non-qualifying group. The correlation of the split jump values in the qualifying group is found in the long jump and point feet variables. This means that although the physical characters are almost all the same, the split jump movement in the non-qualification / beginner group is more the role of the weight and leg length factors that support it. This is in line with the opinion that gymnastic rhythmic novice athletes have not used explosive power much but flexibility and physical characteristics to support performance in a series of motion [20]. Beginner gymnasts who begin training aged 6-7 years have a developmental period of Flexibility at age 7- 11 years $[22,23]$. As increased flexibility reduces muscle stiffness, muscle tissue at this age allows a greater range of joints to support the movement to be achieved. However, the flexibility variable determines the success in performing movements and the development of more complex movements. The finding contradicts friends that there is no effect of flexibility on jumping movement performance in beginner athletes aged $7 \pm 3$ years [20]. Basic locomotor motion training with various training models for novice athletes needs to be intensified [21]. In the qualifying group, the performance value of the split leap was correlated and played a greater role in the 
explosive power of the legs and the point feet. Junior and senior athletes will enter the stages of developing strength and flexibility to support their performance. The split leap move requires a kite of a certain height to give it a chance to perform the split move. This makes the leg muscle explosive power required in the split leap movement. Leg strength during jumping and coordinative movement in rhythm were linearly correlated with the elements of the jumping motion by $65 \%$ [20]. This is supported by the findings of this study in the regression analysis (Table 5) that the prediction variable, in general, is the explosive power characteristics represented by the high jump, the physical characters represented by the length of the legs, and the flexibility represented by the point feet has a significant effect on the split leap movement. The split jump movement is a coordinated series of motion from starting, hovering and landing. The split leap is one of the basic motion elements in rhythmic gymnastics by combining elements of leg flexibility and jumping power [24]. The asymmetrical motion of the leg stretching through the air is the split leap definition [25]. The split leap movement is divided into two types, namely the forward split leap and the side split leap. The difference between the forward split leap and the side split leap is the split direction when hovering. In line with the findings of Galan et al. that the split leap movement is related to the ankle extension, the length of the kite, and the take-off [26]. Gymnasts in hovering require optimal height over a while, this can be achieved by the strength of the leg repulsion or the physical characteristics of the long legs. Hip and ankle strength helps balance every movement in rhythmic gymnastics [27]. One of the important points in this study is the $32 \%$ split leap movement supported by the effective contribution of each variable point feet of $12.5 \%$, leg length $14.5 \%$, and jump height of $4.9 \%$ (Table 6 ). This shows the size of the influence of the variable flexibility, anthropometrics, and physical strength in the split leap movement. Rhythmic gymnastics has characteristics of the appearance of movements with high difficulty which combines anthropometrics [28] with other components such as flexibility, power, psychology, and other factors. [29] Rhythmic gymnasts have a slim profile, long legs, and a normal body mass index [30,31]. Other variables that can predominantly influence the split leap movement that was not observed in this study are psychological factors, length of exercise, fitness variables which include coordination and movement speed, and pelvic ring of motion.

\section{Conclusions}

The split leap requires flexibility of the leg, limb length, and leg power in which the variation of the contribution varies according to the level, anthropometrics has the greatest contribution followed by the flexibility of the leg muscles and leg power. Anthropometric, lower limb flexibility, and explosive power effectively distinguish between qualifications and non-qualification in youth rhythmic gymnastics, leg length, explosive power, and leg flexibility have a greater effect on the split leap score. This emphasizes the importance of selecting a rhythmic gymnast seed. More emphasis is placed on scientific analysis of the ideal posture form for rhythmic gymnasts and training at this age as a prerequisite for technical development. Further research should examine what physical fitness variables play a role in the split leap movement performed in combination with a device or without a tool.

\section{REFERENCES}

[1] Miletić D, Katić R, Maleš B. Some anthropologic factors of performance in rhythmic gymnastics novices. Coll Antropol. Vol.28, No.2.2004, Url: https://hrcak.srce.hr/5602;

[2] Gateva M. Investigations in rhythmic gymnastics. In: The Science of Gymnastics. Page.45-54, 2011 ;

[3] Silva CC, Silva LF, Santos CR, Goldberg TBL, Ramos SP, Venancio EJ. Genetic polymorphism on the flexibility of elite rhythmic gymnasts: State of art. Apunts Medicina de l'Esport. Vol.54. Issue 201. Page 27-35, 2019. DOI: https://doi.org/10.1016/j.apunts.2018.10.001;

[4] Georgopoulos, N.A., Theodoropoulou, A., Roupas, N.D. et al. Growth velocity and final height in elite female rhythmic and artistic gymnasts. Hormones 11, 61-69 (2012). DOI; https://doi.org/10.1007/BF03401538;

[5] Ávila-Carvalho L, Klentrou P, Palomero M da L, Lebre E. Body composition profile of elite group rhythmic gymnasts. The Science of Gymnastics, Vol.4. issue 1, Page 21-32, 2012; url:https://www.researchgate.net/profile/Panagiota-Klentrou /publication/289274766_Body_composition_profile_of_elit e_group_rhythmic_gymnasts/links/5849e50a08aed5252 $\bar{b} \mathrm{cb}$ e $\overline{77}$ c/Body-composition-profile-of-elite-group-rhythmic-gy mnasts.pdf

[6] Aji Putra, Ranu. Software Tentang Fleksibilitas Atlet Senam. J Phys Educ Heal Sport. Vol 1 No 1, 2014, url; https://journal.unnes.ac.id/nju/index.php/jpehs/article/view/ 3007 ;

[7] Dounskaia N. Control of human limb movements: The leading joint hypothesis and its practical applications. Exerc Sport Sci Rev., Vol 38(4): 201-208, 2010. DOI: 10.1097/JES.0b013e3181f45194;

[8] Santos AB, Lemos ME, Lebre E, Carvalho LÁ. Active and passive lower limb flexibility in high level rhythmic gymnastics. Sci Gymnast J.Vol 7. Issue 2 : page 55-66, 2015; https://cifi2d.fade.up.pt/files/scgym722015article-6.pdf

[9] Boligon L, Deprá PP, Rinaldi IPB. Influence of flexibility in the execution of movements in rhythmic gymnastics. Acta Sci Heal Sci. Vol 7, No. 2, 2015. DOI : https://doi.org/10.4025/actascihealthsci.v37i2.21615

[10] Battaglia C, D’Artibale E, Fiorilli G, Piazza M, Tsopani D, Giombini A, et al. Use of video observation and motor 
imagery on jumping performance in national rhythmic gymnastics athletes. Hum Mov Sci.Vol. 38. Pages.225-234 2014, DOI : https://doi.org/10.1016/j.humov.2014.10.001 ;

[11] Hutchinson MR, Tremain L, Christiansen J, Beitzel J. Improving leaping ability in elite rhythmic gymnasts. Med Sci Sports Exerc. Vol.30. Issue 10, Pages 1543-1547, 1998;

[12] Ives JC, Shelley GA. Psychophysics in functional strength and power training: Review and implementation framework. Journal of Strength and Conditioning Research. Vol 17. No.1, Pages. 177-186.2003. https://www.researchgate.net/profile/J effrey-Ives/publication/10905316_Psychophysics in_Functi onal Strength and Power Training Review and Impleme ntation_Framework/links/5762944a08ae5df6d5b1e8d8/Psyc hophysics-in-Functional-Strength-and-Power-Training-Revi ew-and-Implementation-Framework.pdf

[13] Mkaouer B, Amara S, Tabka Z. Split leap with and without ball performance factors in rhythmic gymnastics. Sci Gymnast J. Vol.4, Issue. 2. No.75-81, 2012; https://www.researchgate.net/profile/Zoe-Knowles/publicati on/236022553_Developing_pre-performance routines_for acrobatic_gymnastics_A_case_study_with_a_youth_tumbli ng_gymnast/links/02e $\overline{7}$ e $\overline{5} 3032 \mathrm{fd} 7 \mathrm{~b} 8 \overline{128000000 / D e v e l o p i n g}$ -pre-performance-routines-for-acrobatic-gymnastics-A-case -study-with-a-youth-tumbling-gymnast.pdf\#page $=77$

[14] Culjak Z, Miletic D, Kalinski SD, Kezic A, Zuvela F. Fundamental movement skills development under the influence of a gymnastics program and everyday physical activity in seven-year-old children. Iran J Pediatr. Vol.24 no.2, Pages. 124-130, 2014; https://www.ncbi.nlm.nih.gov/p mc/articles/PMC4268830/

[15] Šimůnková I, Novotná V, Chrudimský J. Contribution of gymnastic skills to the educational content of phy- sical literacy in elementary school children and youth. In: Sport and Quality of Life 2013. 2013. Url.https://www.researchgate.net/profile/Patryk-Stecz/publi cation/263651749_Physical_activity_stress_coping_and_lif e_satisfaction_in patients_undergoing total_hip_replaceme nt/links/53e393890cf23a7ff74966ce/Physical-activity-stress -coping-and-life-satisfaction-in-patients-undergoing-total-hi p-replacement.pdf\#page $=129$

[16] Alwiyah Islamia FJ. Analisis Skor Rangkaian Gerak Senam Ritmik Pada Alat Pita. J Prestasi Olahraga. 2019;2(3):1-5. Url:https://jurnalmahasiswa.unesa.ac.id/index.php/jurnal-pre stasi-olahraga/article/view/30736

[17] Fajar sri; Endang rini; Ratna budiarti; Iriani. Ritmik sportif. Yogyakarta: LPPM UNY; 2018. url https://eprints.uny.ac.id /69845/1/tesis-endang\%20murti\%20sulistyowati-17711251 073.pdf

[18] Gontarev S, Zivkovic V, Velickovska LA, Naumovski M. First normative reference of standing long jump indicates gender difference in lower muscular strength of Macedonian school children. Health (Irvine Calif). Vol.6.No.1 2014 DOI:10.4236/health.2014.61016;

[19] Howard IS, Ingram JN, Wolpert DM. Separate representations of dynamics in rhythmic and discrete movements: Evidence from motor learning. J Neurophysiol. 2011 Doi: https://doi.org/10.1152/jn.00780.2010 ;

[20] Miletic D, Sekulic D, Wolf-Cvitak J. The leaping performance of 7-year-old novice rhythmic gymnasts is highly influenced by the condition of their motor abilities. Kinesiology. Vol. 36 No.1 Pages 35-43, 2004 url : file:///C:/Users/MYLENO 1/AppData/Local/Temp/35_43M iletic.pdf

[21] Palmizal A., Dian Pujianto, Nurkadri, Anak Agung Ngurah Putra Laksana, "Development of a Creative Gymnastics Model to Improve Basic Locomotor Movements for Students in Elementary School," International Journal of Human Movement and Sports Sciences, Vol. 8, No. 6A, pp. 78 - 84, 2020. https://doi.org/10.13189/saj.2020.080714

[22] Rhodri S L, Jon L O, Avery D F, Gregory D M, Mark B DSC. Chronological age vs biological maturation: implications for exercise programming in youth. J strength Cond Res. Vol.28. Issue 5 pages. 1454-1464, 2014 Doi 10.1519/JSC.0000000000000391

[23] Donti O, Bogdanis GC, Kritikou M, Donti A, Theodorakou $\mathrm{K}$. The relative contribution of physical fitness to the technical execution score in youth rhythmic gymnastics. J Hum Kinet. 2016, Doi : https://doi.org/10.1515/hukin-20150183 ;

[24] Polat SÇ, Günay M. Comparison of Eight Weeks Rhythmic Gymnastics, Pilates and Combined Training in Terms of Some Physical, Physiological and Motoric Parameters. Int J Hum Mov Sport Sci. vol.4, no.4, Pages 61-69. 2016, Url: https://avesis.gazi.edu.tr/yayin/b81ad1d3-072b-48d9-ac19-4 b92fbfdab06/comparison-of-eight-weeks-rhythmic-gymnast ics-pilates-and-combined-training-in-terms-of-some-physica 1-physiological-and-motoric-parameters

[25] Tincea R-M. "The Development Of Mobility And Coordination In Rhythmic Gymnastics Performance At Children And Hopes Level.” Ser IX Sci Hum Kinet. 2019;

[26] Rodríguez Galán LM, Gómez-Landero Rodríguez LA. Performance variables and technical penalties of the split leap. Rev Int Med y Ciencias la Act Fis y del Deport. Vol. 12(61) No., 2019, Doihttps://doi.org/10.31926/but.shk.2019 .12 .61 .19

[27] Sobera M, Rutkowska-Kucharska A. Postural Control in Female Rhythmic Gymnasts in Selected Balance Exercises: A Study of Two Cases. Polish J Sport Tour. 2019 Doi: https://doi.org/10.2478/pjst-2019-0001 ;

[28] Douda HT, Toubekis AG, Avloniti AA, Tokmakidis SP. Physiological and anthropometric determinants of rhythmic gymnastics performance. Int J Sports Physiol Perform. Vol3 Issue ;1, 2008, Doi. https://doi.org/10.1123/ijspp.3.1.41.

[29] Bobo-Arce M, Méndez-Rial B. Determinants of competitive performance in rhythmic gymnastics. a review. J Hum Sport Exerc. 2013; Url http://hdl.handle.net/10045/32101

[30] Di Cagno A, Baldari C, Battaglia C, Guidetti L, Piazza M. Anthropometric characteristics evolution in elite rhythmic gymnasts. Ital J Anat Embryol. Vol.113(1):29-35. 2008, url https://www.researchgate.net/profile/Laura-Guidetti/publica tion/5359893_Anthropometric_characteristics_evolution_in elite_rhythmic_gymnasts/links/0912f51273508e161b0000 $\overline{0} 0 /$ Anthropometric-characteristics-evolution-in-elite-rhythm ic-gymnasts.pdf

[31] Arriaza E, Rodríguez C, Carrasco C, Mardones C, Niedmann L, López-Fuenzalida A. Anthropometric Characteristics of Elite Rhythmic Gymnasts. Int J Morphol.Vol.34 No.1 Pages 17-22 2016; Url https://hdl.handle.net/20.500.12536/475. 